This document was prepared in conjunction with work accomplished under Contract No. DE-AC09-96SR18500 with the U. S. Department of Energy.

\title{
DISCLAIMER
}

This report was prepared as an account of work sponsored by an agency of the United States Government. Neither the United States Government nor any agency thereof, nor any of their employees, nor any of their contractors, subcontractors or their employees, makes any warranty, express or implied, or assumes any legal liability or responsibility for the accuracy, completeness, or any third party's use or the results of such use of any information, apparatus, product, or process disclosed, or represents that its use would not infringe privately owned rights. Reference herein to any specific commercial product, process, or service by trade name, trademark, manufacturer, or otherwise, does not necessarily constitute or imply its endorsement, recommendation, or favoring by the United States Government or any agency thereof or its contractors or subcontractors. The views and opinions of authors expressed herein do not necessarily state or reflect those of the United States Government or any agency thereof. 


\section{Cesium Concentration in MCU Solvent}

by

DARREL WALKER

Westinghouse Savannah River Company

Savannah River Site

Aiken, South Carolina 29808

Additional Authors:

DOE Contract No. DE-AC09-96SR18500

This paper was prepared in connection with work done under the above contract number with the U. S. Department of Energy. By acceptance of this paper, the publisher and/or recipient acknowledges the U. S. Government's right to retain a nonexclusive, royalty-free license in and to any copyright covering this paper, along with the right to reproduce and to authorize others to reproduce all or part of the copyrighted paper. 
WSRC-RP-2005-01970, Rev. 0

Keywords: Waste processing, solvent extraction, liquid waste, cesium, $\mathrm{MCU}$

Retention: Permanent

\section{CESIUM CONCENTRATION IN MCU SOLVENT}

\section{Darrel D Walker}

January 18, 2006

Washington Savannah River Company Savannah River Site

Aiken, SC 29808

Prepared for the U.S. Department of Energy Under Contract Number DE-AC09-96SR18500

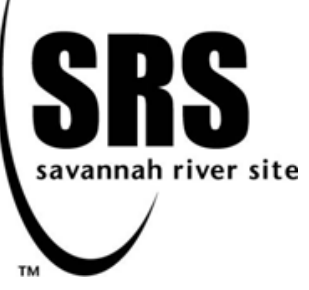


WSRC-RP-2005-01970, Rev. 0

REVIEWS AND APPROVALS

Author:

$\frac{\text { Darrel G, Welles }}{\text { D. D. Walker, SRNL Chemical Science \& Technology }} \frac{1 / 18 / 06}{\text { Date }}$

Technical Reviewer:

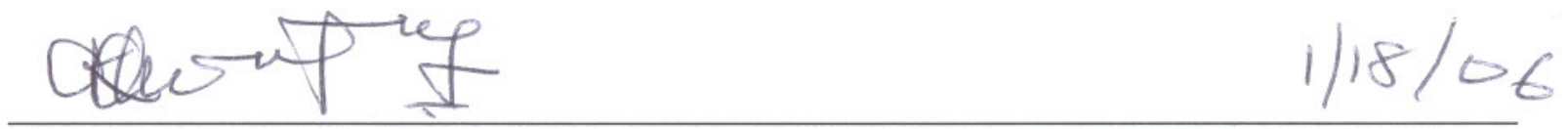

K. Adu-Wusu, SRNL Chemical Science \&Technology

Date

SRNL Management:

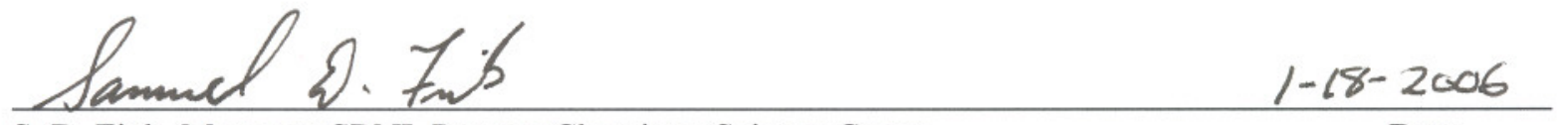

S. D. Fink, Manager, SRNL Process Chemistry Science Group

Date

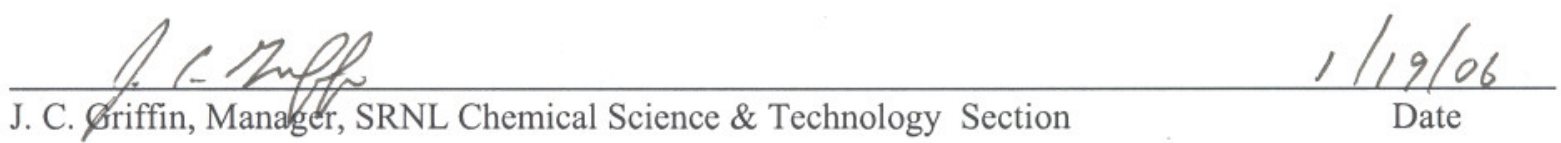

Customer:

BlOom

K. P. Burrows, CBU Modular CSSX Unit Design Authority Manager

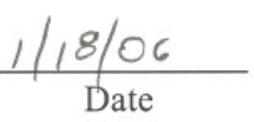

Page 2 of 10 
WSRC-RP-2005-01970, Rev. 0

\title{
CESIUM CONCENTRATION IN MCU SOLVENT
}

\author{
By D. D. Walker
}

\section{Summary}

During Modular Caustic-Side Solvent Extraction (CSSX) Unit (MCU) operations, Cs-137 concentrations in product streams will vary depending on the location in the process and on the recent process conditions. Calculations of cesium concentrations under a variety of operating conditions reveal the following.

- Under nominal operations with salt solution feed containing 1.1 Ci Cs-137 per gallon, the maximum Cs-137 concentration in the process will occur in the strip effluent (SE) and equal 15-16.5 $\mathrm{Ci} / \mathrm{gal}$.

- Under these conditions, the majority of the solvent will contain 0.005 to

$0.01 \mathrm{Ci} / \mathrm{gal}$, with a limited portion of the solvent in the contactor stages containing $\sim 4 \mathrm{Ci} /$ gal.

- When operating conditions yield product near $0.1 \mathrm{Ci}$ Cs-137/gal in the decontaminated salt solution (DSS), the SE cesium concentration will be the same or lower than in nominal operations, but majority of the stripped solvent will increase to $\sim 2-3 \mathrm{Ci} / \mathrm{gal}$.

- Deviations in strip and waste stream flow rates cause the largest variations in cesium content.

- If strip flow rates deviate by $-30 \%$ of nominal, the $\mathrm{SE}$ will contain $\sim 23 \mathrm{Ci} / \mathrm{gal}$, although the cesium content of the solvent will increase to only $0.03 \mathrm{Ci} / \mathrm{gal}$.

- If strip flow rate deviates by $-77 \%$ (i.e., $23 \%$ of nominal), the SE will contain 54 $\mathrm{Ci} /$ gal and solvent will contain $1.65 \mathrm{Ci} /$ gal. At this point, the product DSS will just reach the limit of $0.1 \mathrm{Ci} /$ gal, causing the DSS gamma monitors to alarm.

- Moderate $(+10$ to $+30 \%)$ deviations in waste flow rate cause approximately proportional increases in the SE and solvent cesium concentrations.

Recovery from a process failure due to poor cesium stripping can achieve any low cesium concentration required. Passing the solvent back through the contactors while recycling DSS product will produce a $\sim 70 \%$ reduction during one pass through the contactors (assuming the stripping $\mathrm{D}$ value is no worse than 0.36 ). If the solvent is returned to the solvent hold tank (containing additional, unstripped solvent), 3.3 tank turnovers will reduce the cesium content by an order of magnitude. Under these conditions, the solvent cesium concentration can be reduced to $<0.03 \mathrm{Ci} /$ gal during 8 hours at nominal solvent flow rates $(2.8 \mathrm{gpm})$.

\section{Introduction}

During operation of the MCU, radioactive cesium will be present in the aqueous and organic process streams. Because of its penetrating gamma radiation, Cs-137 is a radiation hazard. The extraction portion of the CSSX process removes cesium from the high-level waste stream and concentrates it in the organic solvent. Following extraction, the cesium becomes further concentrated when stripped from the solvent into a dilute nitric acid stream (called Strip Effluent, or SE). The concentrated cesium solutions produce a radiation hazard affecting the MCU safety 
analysis, plant maintenance, and spent solvent disposal plans. Numerous factors affect the maximum concentration of cesium in the SE and solvent, including the concentration of cesium in the waste, the mass transfer efficiency (for extraction, scrub, and strip operations), and the flow rates of the various process streams. The effects of these factors on the cesium concentrations in the process streams were evaluated using the Spreadsheet Algorithm for Stagewise Solvent Extraction (SASSE). ${ }^{1}$ This report summarizes cesium estimates in the solvent and SE for normal operations, for changes in flow rates, and for degraded solvent (poor stripping).

\section{Calculations}

Researchers used the SASSE spreadsheet to calculate cesium concentrations in the MCU process streams. Table 1 lists the input parameters required for the SASSE calculations. These calculations included two control cases, the design case and a nominal operating case. The design case uses values of certain parameters that are conservative for design (i.e., estimating the number of stages required), but not conservative for estimating the highest cesium concentrations. SASSE produces values for the cesium concentration in each output stream (DSS, SE, Solvent) and in each phase of every contactor.

Researchers varied several of the parameters to determine their impact on cesium concentrations in the system. In most cases, the variations were tested only on the Nominal Case. Several of the parameters were not tested because they are fixed by the current design (number of contactor stages) or have little impact on the cesium calculations (phase ratio, carryover, and liquid volume in contactor). ${ }^{2}$

The current study does not include a systematic investigation of parameters to locate the highest cesium concentrations possible in the solvent or SE. In particular, effects of varying two or more parameters at the same time were not studied.

Additional calculations examined the potential to strip cesium after the stripping D value increased to 0.3. At this point, it would be difficult to produce acceptable DSS product and the stripping would not be allowed to degrade further. The MCU could be temporarily configured to strip the degraded solvent until the cesium concentration was acceptably low to allow removal from the facility. A SASSE case was developed to calculate the efficiency of this process. The SASSE parameter values in Table 1 were used with the following exceptions.

- Strip D value:

- Cesium in solvent stream:

- Waste cesium concentration:

- Solvent recycle:
0.36

$1 \mathrm{Ci} / \mathrm{gal}$

$0 \mathrm{Ci} /$ gal (i.e., use recycled DSS), and

No (i.e., solvent passed through contactors once).

The SASSE result showed that under these conditions, $69 \%$ of the cesium is removed in one pass. This value was used to evaluate changes in the cesium concentration in the solvent hold tank assuming a well-mixed tank. Under this assumption, 3.34 passes of solvent through the contactors produced a $90 \%$ drop in cesium concentration in the tank (i.e., one order of magnitude decrease). At nominal process conditions (i.e., 200 gallons of solvent inventory and $2.83 \mathrm{gpm}$ solvent flow rate), approximately 4 hours of recycling achieves $90 \%$ reduction in cesium. 
WSRC-RP-2005-01970, Rev. 0

TABLE 1. SASSE Parameters for Control Cases and Variations Used in Calculations

\begin{tabular}{|c|c|c|c|}
\hline \multirow[t]{2}{*}{ Parameter } & \multicolumn{3}{|c|}{ Parameter Value } \\
\hline & Design Case & Nominal Case & Variations \\
\hline $\begin{array}{l}\text { Contactor } \\
\text { stages }\end{array}$ & $\begin{array}{l}7 \text { extraction } \\
2 \text { scrub } \\
7 \text { strip } \\
\end{array}$ & $\begin{array}{l}7 \text { extraction } \\
2 \text { scrub } \\
7 \text { strip } \\
\end{array}$ & None \\
\hline $\begin{array}{l}\text { Phase ratio } \\
\text { (Org./Aq.) }\end{array}$ & $\begin{array}{ll}\text { Extraction } & 0.3125^{*} \\
\text { Scrub } & 5.0 \\
\text { Strip } & 5.0 \\
\end{array}$ & $\begin{array}{ll}\text { Extraction } & 0.3125^{*} \\
\text { Scrub } & 5.0 \\
\text { Strip } & 5.0 \\
\end{array}$ & None \\
\hline Flow rates & $\begin{array}{l}\text { Waste } 8.5 \mathrm{gpm}(32.2 \mathrm{~L} / \mathrm{m}) \\
\text { Solvent } 2.83(10.7) \\
\text { Scrub/strip } 0.567(2.145)\end{array}$ & $\begin{array}{l}\text { Waste } 8.5 \mathrm{gpm}(32.2 \mathrm{~L} / \mathrm{m}) \\
\text { Solvent } 2.83(10.7) \\
\text { Scrub/strip } 0.567(2.145)\end{array}$ & $\begin{array}{l} \pm 30 \% \\
\pm 30 \% \\
\pm 30 \% \\
\end{array}$ \\
\hline $\begin{array}{l}\text { Stage } \\
\text { Efficiency }\end{array}$ & $\begin{array}{ll}\text { Extraction } & 80 \% \\
\text { Scrub/strip } & 80 \% \\
\end{array}$ & $\begin{array}{ll}\text { Extraction } & 95 \% \\
\text { Scrub/strip } & 90 \% \\
\end{array}$ & None \\
\hline Carryover & $\begin{array}{lll}\mathrm{O} \text { in A } & \text { Extraction } & 0.0002 \\
& \text { Scrub/strip } & 0.003 \\
\mathrm{~A} \text { in } \mathrm{O} & \text { Extraction } & 0.001 \\
& \text { Scrub/strip } & 0.001\end{array}$ & $\begin{array}{lll}\mathrm{O} \text { in A } & \text { Extraction } & 0.0002 \\
& \text { Scrub/strip } & 0.003 \\
\mathrm{~A} \text { in } \mathrm{O} & \text { Extraction } & 0.001 \\
& \text { Scrub/strip } & 0.001\end{array}$ & None \\
\hline $\begin{array}{l}\text { Liquid } \\
\text { volume in } \\
\text { contactor }\end{array}$ & $\begin{array}{lll}\text { Extraction } & 5 \text { gal }(18.9 \mathrm{~L}) \\
\text { Scrub/strip } & 1.5 \quad(5.7)\end{array}$ & $\begin{array}{ll}\text { Extraction } & 5 \text { gal }(18.9 \mathrm{~L}) \\
\text { Scrub/strip } & 1.5 \quad(5.7)\end{array}$ & None \\
\hline D values & $\begin{array}{ll}\text { Extraction } & 8 \\
\text { Scrub 1 \& 2 } & 0.6 \\
\text { Strip 1-7 } & 0.16\end{array}$ & $\begin{array}{lc}\text { Extraction } & 16.3 \\
\text { Scrub 1 } & 2 \\
\text { Scrub 2 } & 1 \\
\text { Strip 1 } & 0.16 \\
\text { Strip 2 } & 0.10 \\
\text { Strip 3-7 } & 0.05\end{array}$ & $\begin{array}{l}3.6,5.7,20 \& 24 \\
0.16 \text { to } 3 \\
0.16 \text { to } 3 \\
0.21-0.47 \\
0.21-0.47 \\
0.21-0.47\end{array}$ \\
\hline Input Cs & $1.1 \mathrm{Ci} / \mathrm{gal}$ & $1.1 \mathrm{Ci} / \mathrm{gal}$ & $+10 \%$ \\
\hline $\begin{array}{l}\text { Output Cs } \\
\text { (DSS) }\end{array}$ & $\leq 0.1 \mathrm{Ci} / \mathrm{gal}$ & $\leq 0.1 \mathrm{Ci} / \mathrm{gal}$ & $+100 \%$ \\
\hline
\end{tabular}

\section{Results and Discussion}

Table 2 lists the results of all calculations. Portions of this table are repeated in the following discussions of the effects of changes in individual parameters.

\section{Design and Nominal Cases}

The results for the Design and Nominal cases (Table 2, Lines 1 and 2) differ significantly in the cesium concentration in the solvent hold tanks and the cesium in the DSS. Both values are higher in the Design case due largely to the low D values used in the extraction and strip contactors and in the assumed efficiency of the contactor stages. The results indicate the cesium concentration in the solvent can vary considerably. In general, when the MCU process operates near the maximum limit of acceptable waste compositions (i.e., as the cesium concentration in 


\begin{tabular}{|c|c|c|c|c|c|c|}
\hline & Case $^{\mathrm{a}}$ & Changed Parameter & \multicolumn{4}{|c|}{ Cesium Concentration (Ci/gal) } \\
\hline & & & SE & $\begin{array}{c}\text { Solvent } \\
\text { Hold Tank }\end{array}$ & $\begin{array}{l}\text { Solvent in } \\
\text { Contactor }\end{array}$ & DSS \\
\hline 1 & Design & & 15.6 & 0.34 & 4.8 & 0.057 \\
\hline 2 & Nominal & & 16.4 & 0.0056 & 3.9 & 0.0004 \\
\hline 3 & Nominal & $\begin{array}{l}\text { High extraction } \\
\text { D value }(20)\end{array}$ & 16.5 & 0.0056 & 3.9 & 0.0003 \\
\hline 4 & Nominal & $\begin{array}{l}\text { High extraction D } \\
\text { value (24) }\end{array}$ & 16.5 & 0.0056 & 3.9 & 0.0002 \\
\hline 5 & Design & $\begin{array}{l}\text { Low extraction D } \\
\text { value (5.7) }\end{array}$ & 14.9 & 0.33 & 4.5 & $\begin{array}{l}0.101 \\
\text { (at process limit) }\end{array}$ \\
\hline 6 & Nominal & $\begin{array}{l}\text { Low extraction } \\
\text { D value (3.6) }\end{array}$ & 14.9 & 0.0051 & 3.5 & $\begin{array}{l}0.106 \\
\text { (at process limit) }\end{array}$ \\
\hline 7 & Design & High Cs feed $(+10 \%)$ & 17.1 & 0.38 & 5.2 & 0.062 \\
\hline 8 & Nominal & $(1.21 \mathrm{Ci} / \mathrm{gal})$ & 18.1 & 0.0062 & 4.3 & 0.0004 \\
\hline 9 & Nominal & $\begin{array}{l}\text { Low Cs feed } \\
(0.7 \mathrm{Ci} / \mathrm{gal})\end{array}$ & 10.5 & 0.0036 & 2.5 & 0.0003 \\
\hline 10 & Design & $\begin{array}{l}\text { High scrub D value } \\
(2.0)\end{array}$ & 15.6 & 0.34 & 3.8 & 0.054 \\
\hline 11 & Design & $\begin{array}{l}\text { High scrub D value } \\
(3.0)\end{array}$ & 15.6 & 0.34 & 3.7 & 0.054 \\
\hline 12 & Nominal & $\begin{array}{l}\text { High scrub D value } \\
(3.0)\end{array}$ & 16.5 & 0.0056 & 3.5 & 0.0004 \\
\hline 13 & Design & $\begin{array}{l}\text { Low scrub D value } \\
(0.16)\end{array}$ & 15.3 & 0.34 & 9.3 & 0.070 \\
\hline 14 & Nominal & $\begin{array}{l}\text { Low scrub D value } \\
(0.16)\end{array}$ & 16.5 & 0.0056 & 10.5 & 0.0005 \\
\hline 15 & Design & $\begin{array}{l}\text { High strip } \\
\mathrm{D} \text { value }(0.21)\end{array}$ & 14.8 & 0.73 & 5.1 & $\begin{array}{l}0.105 \\
\text { (at process limit) }\end{array}$ \\
\hline 16 & Nominal & $\begin{array}{l}\text { High strip } \\
\text { D value }(0.30)\end{array}$ & 14.8 & 1.65 & 5.4 & $\begin{array}{l}0.102 \\
\text { (at process limit) }\end{array}$ \\
\hline 17 & Nominal & $\begin{array}{l}\text { High strip } \\
\text { D value }(0.44)\end{array}$ & 13.3 & 3.2 & 6.9 & $\begin{array}{l}0.199 \\
\text { (at 2X process } \\
\text { limit) }\end{array}$ \\
\hline 18 & Nominal & $\begin{array}{l}\text { High extraction } \\
\text { D value }(20) \\
\text { High strip } \\
\text { D value }(0.33)\end{array}$ & 14.8 & 2.1 & 5.9 & $\begin{array}{l}0.103 \\
\text { (at process limit) }\end{array}$ \\
\hline
\end{tabular}


TABLE 2. Calculated Cesium Concentrations in MCU Process Streams

\begin{tabular}{|c|c|c|c|c|c|c|}
\hline & Case $^{\mathrm{a}}$ & Changed Parameter & \multicolumn{4}{|c|}{ Cesium Concentration (Ci/gal) } \\
\hline & & & SE & $\begin{array}{c}\text { Solvent } \\
\text { Hold Tank }\end{array}$ & $\begin{array}{l}\text { Solvent in } \\
\text { Contactor }\end{array}$ & DSS \\
\hline 19 & Nominal & $\begin{array}{l}\text { High extraction D } \\
\text { value }(20) \\
\text { High strip } \\
\text { D value }(0.50)\end{array}$ & 13.3 & 4.0 & 7.8 & $\begin{array}{l}0.201 \\
\text { (at } 2 \mathrm{X} \text { process } \\
\text { limit) }\end{array}$ \\
\hline 20 & Nominal & $\begin{array}{l}\text { High extraction } \\
\text { D value }(24) \\
\text { High strip } \\
\text { D value }(0.36)\end{array}$ & 14.8 & 2.5 & 6.4 & $\begin{array}{l}0.103 \\
\text { (at process limit) }\end{array}$ \\
\hline 21 & Nominal & $\begin{array}{l}\text { High extraction } \\
\text { D value }(24) \\
\text { High strip } \\
\text { D value }(0.56)\end{array}$ & 13.3 & 4.8 & 8.8 & $\begin{array}{l}0.200 \\
\text { (at } 2 \mathrm{X} \text { process } \\
\text { limit) }\end{array}$ \\
\hline 22 & Nominal & Waste flow $+10 \%$ & 18.1 & 0.0062 & 4.3 & 0.0005 \\
\hline 23 & & Waste flow $+20 \%$ & 19.7 & 0.0068 & 4.7 & 0.0005 \\
\hline 24 & & Waste flow $+30 \%$ & 21.4 & 0.0073 & 5.0 & 0.0006 \\
\hline 25 & & Waste flow $-10 \%$ & 14.8 & 0.0051 & 3.5 & 0.0003 \\
\hline 26 & Nominal & Strip flow $+10 \%$ & 14.9 & 0.0036 & 3.9 & 0.0003 \\
\hline 27 & & Strip flow $+20 \%$ & 13.7 & 0.0024 & 3.9 & 0.0002 \\
\hline 28 & & Strip flow $+30 \%$ & 12.6 & 0.0017 & 3.9 & 0.0002 \\
\hline 29 & & Strip flow $-10 \%$ & 18.2 & 0.0092 & 3.9 & 0.0006 \\
\hline 30 & & Strip flow $-20 \%$ & 20.4 & 0.016 & 3.9 & 0.0010 \\
\hline 31 & & Strip flow $-30 \%$ & 23.4 & 0.031 & 3.9 & 0.0019 \\
\hline 32 & & $\begin{array}{l}\text { Strip flow - } 77 \% \\
(0.58 \mathrm{gpm})\end{array}$ & 54.1 & 1.65 & 9.9 & $\begin{array}{l}0.101 \\
\text { (at process limit) }\end{array}$ \\
\hline 33 & Nominal & Solvent flow $+10 \%$ & 16.5 & 0.0081 & 3.5 & 0.0005 \\
\hline 34 & & Solvent flow $+20 \%$ & 16.4 & 0.0113 & 3.2 & 0.0007 \\
\hline 35 & & Solvent flow $+30 \%$ & 16.4 & 0.015 & 2.9 & 0.0009 \\
\hline 36 & & Solvent flow $-10 \%$ & 16.5 & 0.0038 & 4.4 & 0.0003 \\
\hline 37 & & Solvent flow $-20 \%$ & 16.5 & 0.0025 & 5.0 & 0.0003 \\
\hline 38 & & Solvent flow $-30 \%$ & 16.5 & 0.0016 & 5.9 & 0.0004 \\
\hline 39 & Nominal & Scrub flow $+30 \%$ & 16.5 & 0.0056 & 4.1 & 0.0004 \\
\hline 40 & & Scrub flow $-30 \%$ & 16.5 & 0.0056 & 3.7 & 0.0004 \\
\hline
\end{tabular}


the DSS stream approaches or exceeds the process objective of $0.1 \mathrm{Ci} / \mathrm{gal}$ ), the cesium concentration in the solvent hold tank will increase.

\section{Extraction D Value}

Design and operation of the MCU process assumed a minimum D value for extraction of 8 . This value occurs in the design case. However, the average waste composition ${ }^{3}$ used in most CSSX testing produces a $\mathrm{D}$ value of 16.3 , which was used in the nominal case. A recent study encompassing a wide range of waste compositions showed $\mathrm{D}$ values can vary from $<1$ to 32 . $^{2}$

Increasing (Table 2, Lines 3 and 4) or decreasing (Table 2, Lines 5 and 6) the extraction D value has little effect on the cesium concentrations in the SE or solvent. Increasing the D value improves cesium removal, thus decreasing the relatively small amount of cesium in the DSS stream. Cesium removed from DSS goes into the SE and solvent, but does not significantly change the large amounts already present. Conversely, decreasing the extraction D value (Table 2, Lines 5 and 6) increases the amount of Cs remaining in the DSS, thus decreasing slightly the amounts in the SE and solvent. The D values selected (5.7 and 3.6) correspond to the point at which acceptable product is no longer produced (DSS [Cs] $>0.1 \mathrm{Ci} / \mathrm{gal})$.

\section{Cs Concentration in Waste}

MCU planning includes a nominal Cs-137 concentration in the waste feed of $1.1 \mathrm{Ci} / \mathrm{gal}{ }^{4}$ In Table 2, comparing Lines 1 and 2 to Lines 7 and 8 shows that moderate increases in the cesium concentration in the feed has a direct and approximately linear impact on the SE and solvent concentrations.

Table 2, Line 9 contains a low value for cesium in the waste $(0.7 \mathrm{Ci} / \mathrm{gal})$ and shows that all stream concentrations will decrease similarly. The value of $0.7 \mathrm{Ci} /$ gal derives from current processing plans that indicate the waste going to $\mathrm{MCU}$ will contain a maximum of $0.7 \mathrm{Ci} / \mathrm{gal}$, significantly lower than the value of $1.1 \mathrm{Ci} /$ gal used in the nominal case. ${ }^{4}$

\section{Scrub D Value}

As seen in Table 2, Lines 10-14, changing the scrub D value in SASSE did not significantly impact the SE or solvent cesium concentrations. This result occurs because the strip D values remained constant in this study. In actual operation, poor scrubbing will adversely impact the stripping in the initial strip stages and result in cesium concentration changes described below for variations in the strip D values. The impact of combined effects was not investigated.

\section{Strip D Values}

Incomplete stripping results when the strip D value increases. This will occur, for instance, when lipophilic anionic compounds (such as soaps, detergents, or surfactants) are scavenged by the solvent and exceed the capacity of the tri-n-octyl amine to suppress their effects. Incomplete stripping causes the concentration of cesium to increase in the solvent and decrease in SE (see Table 2, Lines 15 to 21). As a natural consequence of high cesium in the solvent, the process will begin to suffer from poor cesium removal from the waste, causing the DSS stream to exceed $0.1 \mathrm{Ci} /$ gal. During process operations, the poor quality of the DSS stream will be noted in the gamma monitor readings, thus providing a limit on the cesium concentration in the solvent of 
$\sim 3 \mathrm{Ci} / \mathrm{gal}$. The exact cesium concentration depends on the extraction $\mathrm{D}$ value for the particular waste composition being processed.

\section{Process Flow Rates}

Changes in process flow rates show the greatest potential for affecting cesium concentration in the SE and solvent (see Table 2, Lines 21 to 39). Changes in waste flow rate cause proportional changes in the cesium concentrations in SE, solvent, and contactors (i.e., compare Table 2, Lines 1-2 to Lines 22-25). Increases in strip flow rate reduce cesium concentrations (i.e., compare Table 2, Lines 1-2 to Lines 26-28). However, decreases in strip flow rate cause very large increases in the SE cesium concentration (i.e., compare Table 2, Lines 1-2 to Lines 29-32). A $30 \%$ drop in strip flow increases SE cesium from a nominal $16.4 \mathrm{Ci} / \mathrm{gal}$ to $23.4 \mathrm{Ci} / \mathrm{gal}$. This concentration occurs in the SE exiting the last strip contactor and will slowly affect the concentration in the SE hold tank if allowed to continue. However, the MCU design includes a gamma monitor on the SE stream that alerts operators when the cesium content increases beyond a predetermined limit. ${ }^{5}$ If the SE gamma monitor failed to work, the problem would eventually become apparent when the cesium content in the DSS exceeds $0.1 \mathrm{Ci} /$ gal, at which point the SE cesium concentration equals $\sim 54 \mathrm{Ci} /$ gal.

Changes in solvent flow rate do not affect cesium in SE, but will affect cesium in the solvent (i.e., compare Table 2, Lines 1-2 to Lines 33-38). However, the effects on solvent are much smaller than found for similar changes in strip flow rate. Changes in scrub flow rates do not affect cesium in the SE or solvent (i.e., compare Table 2, Lines 1-2 to Lines 39-40).

\section{Conclusions}

Under nominal operations - with the flow sheet conditions listed in Table 1 - the SE will contain 15-16.5 Ci Cs-137 per gallon, the solvent will contain 0.005 to $0.01 \mathrm{Ci} /$ gal, and a limited portion of the solvent in the contactor stages will contain up to $4 \mathrm{Ci} /$ gal. When operations approach the DSS limit $(0.1 \mathrm{Ci} / \mathrm{gal})$, likely caused by poor stripping or contactor efficiency, the SE content will be the same, but the solvent content will increase approximately 400 -fold to $\sim 2 \mathrm{Ci} /$ gal, with limited amounts of solvent in the contactor stages containing 3.5 to $6.5 \mathrm{Ci} / \mathrm{gal}$. If strip flow rate controls deviate by as much as $-30 \%$ of nominal, the SE leaving the last strip contactor will contain $\sim 23 \mathrm{Ci} /$ gal and solvent will increase to $0.03 \mathrm{Ci} /$ gal. The cesium concentration in the $\mathrm{SE}$ hold tank will lag the concentration of SE leaving the last strip contactor. A gamma monitor on the SE stream will alert operators to the increase in cesium concentration. If the SE gamma monitor fails to alarm, a strip flow rate deviation of $-77 \%$ (i.e., drop to only $23 \%$ of the nominal value) will produce DSS at the limit of $0.1 \mathrm{Ci} / \mathrm{gal}$ and cause the DSS gamma monitor to alarm. At this point, the process cesium concentrations will equal $54 \mathrm{Ci} / \mathrm{gal}$ in the $\mathrm{SE}$ exiting the last strip contactor, $1.65 \mathrm{Ci} /$ gal in the stripped solvent, and $\sim 10 \mathrm{Ci} /$ gal in limited amounts of solvent in the contactors. The DSS gamma monitor will alarm and drive an interlock that recycles the DSS to the salt feed tank. The introduction of the DSS to the feed solution will cause cesium concentrations to decrease throughout the process.

Most process failure modes will fall into two categories, mechanical failure (i.e., broken contactor, piping leak) or chemistry variation (i.e., insufficient extraction or stripping capability). In the first failure mode, the cesium concentration in the process streams will depend on the 
operating conditions at the time of failure. This could result in the range of the concentrations listed in Table 2, but the bulk of the solvent inventory would most likely match the nominal operations (i.e., Case 2) and contain $0.0056 \mathrm{Ci} /$ gal. In this failure mode, the solvent remains acceptable for continued use (i.e., does not require disposal) but needs a safe storage location during system repairs and maintenance. In contrast, failure by variation in the process chemistry potentially results in much higher cesium concentrations in the solvent. Cesium concentrations could vary between 0.005 to $2.5 \mathrm{Ci} /$ gal if it does not extract (Cases 5 and 6) or of it does not strip (Cases 15, 16, 18, and 20). If a decision is made to dispose of the solvent, compensatory action could reduce the cesium concentration to $<0.03 \mathrm{Ci} /$ gal (or lower) by cycling the solvent and the DSS through the contactors while using fresh scrub and strip solution. Passing the solvent back through the contactors while recycling DSS product will achieve a $69 \%$ reduction in cesium concentration during one pass through the contactors. If the solvent is returned to the solvent hold tank (containing additional, unstripped solvent), 3.34 turnovers will reduce the cesium content by an order of magnitude. Thus, in the worst case $(2.5 \mathrm{Ci} / \mathrm{gal})$, seven turnovers requiring 8 hours at nominal flow rates will reduce the cesium concentration to $<0.03 \mathrm{Ci} /$ gal. Additional processing (i.e., an additional 4 hours), will reduce the cesium to $<0.003 \mathrm{Ci} /$ gal. These results assume stripping becomes no worse than a change in stripping D value to 0.36 (Table 2, Case 20). Alternatively, recycling the solvent through the two wash contactors using an appropriate aqueous wash solution might be the most effective solvent cleanup method.

\section{References}

${ }^{1}$ R. A. Leonard and M. C. Regalbuto, "A Spreadsheet Algorithm for Stagewise Solvent Extraction," Solvent Extraction and Ion Exchange, 12(5), 909-930 (1994).

${ }^{2}$ K. Adu-Wusu, D. D. Walker, and T. B. Edwards, "Waste and Solvent Composition Limits for Modular Caustic-Side Solvent Extraction Unit (MCU)," WSRC-TR-2005-00258, Rev. 0, May 26, 2005.

${ }^{3}$ R. A. Peterson, "Preparation of Simulated Waste Solutions for Solvent Extraction Testing," WSRC-RP-2000-00361, Rev. 0, May 1, 2000.

${ }^{4}$ C. I. Aponte and M. D. Drumm, "MCU Waste Streams Radiological Makeup," X-CLC-H00575.

${ }^{5}$ R. T. McNew, "Evaluation of the Impacts to the Hazard Categorization of MCU due to Increased Cesium Concentration in the Strip Effluent Stream," CBU-SPT-2006-00002, Rev. 0, January 17, 2006.

CC: $\quad$ K. Adu-Wusu, 773-41A

C. I. Aponte, $730-1 \mathrm{~B}$

D. A. Boyce, $730-1 \mathrm{~B}$

K. P. Burrows, 730-1B

E. A. Brass, 730-1B

S. J. Brown, 730-1B

S. D. Fink, 773-A

F. F. Fondeur, 773-A

M. W. Geeting, 730-1B

A. P. Giordano, 730-1B

M. G. Hogue, 707-40B
M. R. Gober, 730-1B

J. C. Griffin, 773-A

W. I. Isom, Jr., 766-H

J. E. Marra, 773-A

R. T. McNew, 730-1B

D. L. McWhorter, 730-1B

C. A. Nash, 773-42A

T. B. Peters, 773-42A

M. R. Poirier, 773-42A

D. D. Walker, 773-A 